\title{
Article
}

\section{Feeling so Hood. Rap, lifestyles and the neighbourhood imaginary in Tunisia}

\author{
Barone, Stefano
}

Available at http://clok.uclan.ac.uk/25202/

Barone, Stefano ORCID: 0000-0003-0437-9452 (2017) Feeling so Hood. Rap, lifestyles and the neighbourhood imaginary in Tunisia. British Journal of Middle Eastern Studies, 46 (1). pp. 88-103. ISSN 1353-0194

It is advisable to refer to the publisher's version if you intend to cite from the work. http://dx.doi.org/10.1080/13530194.2017.1371001

For more information about UCLan's research in this area go to http://www.uclan.ac.uk/researchgroups/ and search for < name of research Group>.

For information about Research generally at UCLan please go to http://www.uclan.ac.uk/research/

All outputs in CLoK are protected by Intellectual Property Rights law, including Copyright law. Copyright, IPR and Moral Rights for the works on this site are retained by the individual authors and/or other copyright owners. Terms and conditions for use of this material are defined in the policies page.

\section{CLoK}

Central Lancashire online Knowledge www.clok.uclan.ac.uk

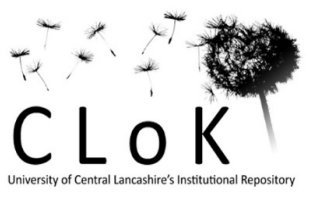


Feeling so Hood. Rap, Lifestyles, and the Neighbourhood Imaginary in Tunisia

\section{Stefano Barone}

Griffith Centre for Social and Cultural Research, Griffith University, Queensland, Australia

Mail Address: via Settembrini 39, 97017 Santa Croce Camerina, Italy

Email address: stefanobarone84@gmail.com

Acknowledgments: The author wishes to thank professor Andy Bennett and Doctor Christine Feldman-Barrett for their supervision at Griffith University, and Inel Tarfa and Sofiane Mabrouk for their help during fieldwork and with translations. 


\title{
Feeling so Hood. Rap, Lifestyles, and the Neighbourhood Imaginary in Tunisia
}

\begin{abstract}
The article examines the role of rap in reimagining the social structure in Tunisia after its 2010/2011 revolution. Before the revolution, the Ben Ali regime imposed a narrative of Tunisian society as mainly middle class; beneath this narrative, the Tunisian folklore hosted multiple markers of social distinction that classified people through their perceived lifestyles: residence, language habits, consumption patterns, religious attitudes. Disadvantaged neighbourhoods were obliterated by the official narrative, and condemned to social spite by the unofficial ones. After the revolution, the success of rap came to 'represent' those quarters and the youth that inhabited them: rappers sang the hoods by criticizing their hard conditions and, at the same time, glorifying the hoods themselves. The vagueness of the social narratives in the country allowed rap musicians to manipulate both the image of the poor neighbourhoods and the idioms of social difference circulating in Tunisia: through this manipulation, they provided a new dignity to the most marginalized sectors of Tunisian society. At the same time, by representing the hoods, rappers could claim social capital and credibility as the 'true' narrators of the new Tunisia. But the reimagination of social narratives was not enough to improve the life conditions of dispossessed youth.
\end{abstract}

Word count: 8159

Keywords: Tunisia, rap, lifestyles, neighbourhoods, social structure.

\section{Introduction}

We live like trash in the dustbin,

I am so poor, I don't have a penny,

I don't wake up early in the morning,

I don't even know what a watch is,

This place is suffocating,

The atmosphere is so gloomy... ${ }^{1}$

These lines come from Houmani (2013), a song by Tunisian artists Hamzaoui Med Amine and Kafon. Houmani is perhaps the most important phenomenon in contemporary Tunisian pop culture: as we will see, such an appeal is certainly connected to the revolution that, between 2010 and 2011, shook Tunisia and the world, initiating the so-called Arab Springs. At the time of my fieldwork in Tunisia, between 2014 and 2015, it was seemingly impossible not to listen to the song. Houmani was blasted by the speakers of car radios, open air shops, lounge bars; children in the slums of Tunis sang it by heart, as did the bourgeois who crowded the disco clubs of the Tunisian coast. In the month of

\footnotetext{
${ }^{1}$ All translations were made by the author with the help of two research participants, Sofiane Mabrouk and Inel Tarfa. Lyrics are not presented here in their literal translation; the author took care of their adaptation to English.
} 
September 2016, the song had about 26 million views on YouTube - that is, around two and a half times the population of Tunisia ${ }^{2}$.

This transversal success is all the more intriguing if we consider the song's theme: Houmani narrates the life of youth in the houma (plur. hwem), a Tunisian word that designates the local neighbourhoods, in particular the 'traditional' ones - those termed, in French, les quartiers populaires. While the word houma does not strictly refer to the slums, it often indicates areas marked by a strong local identity, a community-centred lifestyle, and modest economic conditions. Hence, the concept of houma did not designate a purely physical space: it rather resembled the concept of neighbourhood ideated by Arjun Appadurai - that is, the ambit in which locality is produced as a structure of feeling, as a form of interpersonal proximity ${ }^{3}$.

Such a designation is evident in Houmani: the song title is a neologism that indicates somebody living in the houma and experiencing its life conditions, marked by poverty, boredom, and inanition. Such a theme is underlined by the song video as well: the clip, which costed only 250 Tunisian dinars (less than 100 euros), portrays episodes of street life in Ariana, a city in the North-Western suburbs of Tunis ${ }^{4}$. The guest singer Kafon himself came to represent the ideal houmani: a guy of humble origins who, between 2013 and 2014, served a 10 months sentence in jail for marijuana possession. Kafon thus embodied, at the same time, the destiny of street youth repressed by the police for their lifestyle, and the contiguous one of rappers implicitly harassed by the police because of their art.

Houmani is the product - and the narrative - of some socio-cultural phenomena that were unthinkable before the revolution. It signifies the controversial emergence of rap as an important 'pop' commentary of the new Tunisia ${ }^{5}$, and, at the same time, the appearance of disadvantaged youth and the houma as key loci of Tunisian post-revolutionary history. In this article, I will analyse the connection between these two phenomena, a connection that has in Houmani only its most 'mainstream' example. I will illustrate how rap has been constructed as 'the voice of the houma' and some of the consequences of this identification between rap and the youth from the neighbourhoods. Singing the hwem was, for Tunisian rappers, a source of symbolic capital. At the same time, the houma narrative implied a play with the signifiers of Tunisian social structure (in particular, with the lifestyles circulating in Tunisia). Such a play worked as a precarious technique of empowerment for rappers and disadvantaged youth, and in so doing it revealed some features of Tunisian society itself.

The article aims to use the frameworks and methodologies of the sociology of youth cultures and popular music in order to understand, from an original point of view, the social, cultural, and political context of post-revolutionary Tunisia. It is part of a broader research project about the local rap, metal, and electro music scenes:. the use of scene I make hererefers to the conceptualization of music scenes within the debate on youth subcultures and post-subcultures ${ }^{6}$. In that sense, a scene can be seen as a

\footnotetext{
${ }^{2}$ Houmani's video: https://www.youtube.com/watch?v=mz3p3a4EiXA Accessed 9/11/2016.

${ }^{3}$ Arjun Appadurai, Modernity al large: cultural dimensions of globalization, (Minneapolis: University of Minnesota Press, 1996).

4“"'Houmani": un rap sur la pauvreté se transforme en phénomène de société”, Les Observateurs 15/11/2013 http://observers.france24.com/fr/20131115-tunisie-houmani-hamzaoui-kafon-rap-pauvrete-transforme-phenomene Accessed 4/11/2016.

${ }^{5}$ A non-Tunisian listener might be puzzled by the identification of Houmani as a rap song. The track actually sounds more as a crossover of dancehall reggae and dubstep, modeled on the success Make it bun dem by Skrillex and Damian Marley. Still, perhaps due to the already established rap career of Hamzaoui Med Amine, the song was popularly considered a rap anthem, and so it was represented in the media. Members of the rap scene overtly polemized against this identification, and reputed the success of Kafon as an insult against the "real" Tunisian rap scene.

${ }^{6}$ Andy Bennett and Keith Kahn-Harris, eds. After subculture. Critical studies in contemporary youth culture (Basingstoke: Palgrave/Macmillan, 2004).
} 
space of cultural practices connecting musicians, infrastructures - such as record labels, venues, fanzines, political institutions and the like - and listeners, in a reciprocally influential fashion ${ }^{7}$.

The data I will present come from an eleven months fieldwork that I carried out in Tunisia between 2014 and 2015, exploring the rap scene along with the metal and electro ones. Data come from interviews with rappers and other members of the rap scene; from participant observation at concerts, open mics, recording studios, cafes, and everyday life on the streets; and from the analysis of media sources such as social network sites and newspaper articles. I will now describe the upsurge of the Tunisian rap scene and collocate it into the post-revolutionary panorama. An outline of the Ben Ali regime's political economy will then help contextualizing local understandings of Tunisian lifestyles and social structure. I will thus analyze the role of rap in rethinking those understandings, and I will conclude the paper by describing the limits of rap as a tool for the re-imagination of Tunisian society.

\section{Rap and revolution}

On the $17^{\text {th }}$ of September 2010, police sequestered the fruit and vegetables cart of Tarek Mohammed Bouazizi, a young informal vendor from the city of Sidi Bouzid, in the dispossessed inland of Tunisia. Bouazizi reacted out of frustration, and set himself on fire - he would die two weeks later. The selfimmolation of the young street vendor immediately caused a wave of protests that, within a month, expanded from the Centre and South of Tunisia to reach the well-off coastal area and the most important cities, including the capital Tunis. The president Zine el Abidine Ben Ali, who had governed the country for 23 years, initially reacted by violently repressing the protests. However, he would capitulate on the $14^{\text {th }}$ of January 2011, when he flew off Tunisia. A complex phase of regime change thus began: Tunisia became a multi-party democracy troubled by economic problems, authoritarian temptations, and the constant menace of jihadi terrorism ${ }^{8}$.

Revolts spurred off the condition of social exclusion suffered by the internal regions of the country, and from the failure of the regime in integrating a growing mass of unemployed in the economic system. The uprising had started as a demand for bread and jobs, but soon became a political cry for more democracy and the end of the Ben Ali regime. Along this process, it came to integrate different sectors of Tunisian society and their requests, coalescing them around the common fight against the political establishment. Tunisians felt that the Ben Ali dictatorship had taken their dignity away: the term 'dignity' meant different things to those who revolted - unemployed youth, anti-regime cyberactivists, Islamist militants, or the Tunis lawyers. However, it came to signify a common cause, and thus provided a ground for the desectorialization of the protests and the making of a mass movement ${ }^{9}$.

Rap entered the epic of the Tunisian revolution during the last days of the regime. Hamada Ben Amor, a rapper known as El General, published his song Rayes Lebled (Head of the State) in December $2010^{10}$ : the song was an open letter to Ben Ali, in which the rapper called the president on the injustice and poverty that were strangling the country. Rayes Lebled was not the first protest song written by a Tunisian rapper; however, it resonated with the mounting protests and became a hymn of the revolts

\footnotetext{
${ }^{7}$ On scenes, see Keith Kahn-Harris, Extreme metal: Music and culture on the edge (London: Berg, 2006); Geoff Stahl, " "It's Like Canada Reduced": Setting the Scene in Montreal' in After Subculture (see note 4),

${ }^{8}$ Larbi Chouika and Eric Gobe, Histoire de la Tunisie depuis l'indépendance (Paris: La Découverte, 2015).

${ }^{9}$ Michael Bechir Ayari, 'Des maux de la misère aux mots de la "dignité”'. Revue Tiers Monde 5 (2011) 209-217

${ }^{10}$ Rayes Lebled's video: https://www.youtube.com/watch?v=7yPZE313mk8 Accessed 9/11/2016.
} 
that were spreading through the Middle East and North Africa. The song became iconic with the arrest of El General, on the $6^{\text {th }}$ of January. Ben Amor came to be recognized as one of the 'heroes' of the so-called Arab Spring; international media started to identify rap as the music of the Middle Eastern protests. At the end of 2011, the American magazine Time collocated El General among the most influential characters of the year ${ }^{11}$. The international fame of El General has been widely criticized in the Tunisian rap scene: many rappers contested the credibility of Ben Amor, claiming that he had come from nowhere and was not representative of the scene itself, nor he was particularly skilled as an artist. These criticisms would become fiercer after the revolution, when El General pursued his career as an Islamic rapper, and used his music to campaign for political parties ${ }^{12}$. Still, Rayes Lebled came at the right moment, propelling the appeal of Tunisian rap in the country and to audiences abroad.

Another effect of the Tunisian revolution proved important for the upsurge of the Tunisian rap scene. At the eve of his resignation, Ben Ali made one last attempt to quench the protests: in his last television speech, he claimed that he had 'understood' the protesters, and proposed a series of measures in order to democratize the country and contrast poverty and unemployment. Among those measures, one was immediately enforced: the end of Internet censorship. Since the night of the $13^{\text {th }}$ of January 2011, an array of websites that used to be accessible only through proxies (such as antiregime or porn sites) became legal. Censorship was lifted off YouTube, making it the fundamental vehicle for the diffusion of rap music in Tunisia.

., A small rap scene already existed in Tunisia before 2011. The scene had even produced a veritable star: Balti, who had been the godfather of underground Tunisian rap before crossing over to the mainstream music industry and even singing for the president Ben Ali ${ }^{13}$. However, in the 2000s rap was mostly a submerged reality: concerts were rare, and songs had a limited diffusion, as videoclips on the Facebook accounts of artists or as MP3s that could be downloaded from specialized online forums. Through YouTube, the rap scene has proved able to reach a mass audience that was just unthinkable in the pre-revolutionary period. A generation of young rappers who had surfaced in the last part of the decade - MCs such as Klay BBJ, Vipa, Weld el 15, Madou MC, Phenix, Medusa arose to unprecedented fame. Videos by Klay, Hamzaoui, or Sanfara went over one million views in

${ }^{11}$ On El General and his recognition, see Nouri Gana, 'Rap and Revolt in the Arab World', Social Text no. 30 (2012), 25-53; Yves Gonzalez-Quijano, 'Le nouvel orientalisme et les jeunes rebelles: les rappeurs de la scène arabe', Contretemps, 2013 http://www.contretemps.eu/interventions/nouvel-orientalisme-jeunes-rebelles-rappeurssc\%C3\%A8ne-arabe Accessed 10/11/2016.

${ }^{12}$ By "Islamic rapper" I refer, here, to a wave of rappers singing themes related to political Islam and religion in a broader sense. The most influent example of this kind of rap, in north Africa, is the Algerian MC Lotfi Double Kanon, whom many of my informants claimed as an inspiration. Tunisian rappers such as Psyco-M, C.A.S.A., or Guito-N often sang lyrics on political islam, anti-islamic global plots, infra-Islamic controversies (such as the critique of Wahabism from a Muslim point of view). Some of these artists enjoyed direct support from the Islamic party Ennahdha. Such rappers where sometimes criticized by members of the rap scene for their message-centered rap: according to their critics, Islamic rappers did not pay enough attention to technique and poetry, and thus devalued rap music in an artistic sense. Others criticized these rappers for being corrupted and dependent on the money of political parties. However, it would be hard to consider Islamic rappers a coherent sub-scene, especially since Islamic references were present in many songs of rappers that did not subscribe to the category of "Islamic rappers". On this theme, see Souad Halila, 'Rap and Islamism in post-revolutionary Tunisia: Local idiosyncrasies and global reverberations', in Islamism and Cultural Expression in the Arab world, ed. Abir Hamdar and Lindsey Moore (London: Routledge, 2015), $222-238$. On the relationship between rap and political parties in Tunisia, see Henda Chennaoui, 'Elections 2014: L'underground tunisien récupéré par le politique?', Nawaat, 19/11/2014, http://nawaat.org/portail/2014/11/19/elections-2014-lunderground-tunisien-recupere-par-le-politique/ Accessed 10/11/2016.

${ }^{13}$ Kerim Bouzouita, 'Underground et mainstream: anthropologie des dominations et des résistances musicales'. (PhD diss., Université Paris VIII, 2013). 
one week; rappersfigured in prime time TV shows ${ }^{14}$, and were sometimes represented as 'the real voice of the streets' - much more credible, among Tunisian youth, than the politicians of the new democratic establishment.

YouTube structured the rap scene, the music, and its circulation. 'Views' on the website became the currency of the scene: rappers existed only insofar as they were on YouTube, and their careers were intimately tied to the performance and diffusion of their clips. Consequently, musicians focused on producing singles and videos rather than entire albums. The role of YouTube as a central node of the scene made success in Tunisian rap a mainly virtual affair. Only few artists could monetize their YouTube success ${ }^{15}$, or played live often enough to make a living out of their concert schedule. The undeveloped state of the local rap music industry resulted, for most rappers, in a separation between celebrity and commercial success. In this situation, some artists sought parallel forms of revenue: street hustles and drug dealing; liaisons with political parties (for example, singing at party rallies); or participation in the development and capacity building sector (for example, being paid by international NGOs in order to organize workshops on urban culture for disadvantaged children $)^{16}$. Hence, the vitality of the post-revolutionary rap scene was marked by a series of ambiguities and contradictions. The fame of rappers coexisted with their economic marginalization. Their credibility and popularity were counterbalanced by an atmosphere of social suspicion and moral panic. If rappers represented the street, they carried its stigma as well: they had a reputation for being drug dealers and violent thugs, and their speech (marked by swear words and a street-savvy use of Tunisian dialect) was reputed vulgar and insulting. Politics courted rappers and tried to profit from their cultural capital, but at the same time MCs often encountered fierce repression due to their lifestyle habits (for example, drug consumption and street life) and their musical attacks against the police and the ruling class. The list of rappers persecuted since 2011 (that is, in the time of 'democratization') is disturbingly long: Volcanis Le Roi, Weld El 15, Lady Sam, Madou MC, Emino, Phenix, T-MC, (beatmaker) Brown, Killa MC, Klay BBJ, Kafon are only some of the rap musicians arrested after the revolution. In most cases, rappers have been imprisoned for drug-related offences (smoking a single joint usually caused a one year prison sentence). However, many local activists usually connected crime-related arrests or police harassment with a will to punish artistic dissent, or, more in general, the lifestyles of youth from the Houma ${ }^{17}$. The most famous case of imprisonment, however, concerned rapper Weld el 15, arrested several times for his anti-police song Boulicia Kleb (Policemen are dogs, 2013) ${ }^{18}$.

The ambiguous condition of the rap scene homologically mirrored the one of the disadvantaged hwem and their youth. As with rappers, youth from the neighbourhoods were caught between celebration as

\footnotetext{
${ }^{14}$ For example, the popular prime time show "Labes", on the channel El Hiwar Ettounsi, hosted many famous MCs, such as Madou, Klay, or Vipa. The latter even became the protagonist of a comedy TV series in which he interpreted himself.

${ }^{15}$ Youtube monetization has been rendered possible in Tunisia only in 2014. See "4 ans de YouTube en Tunisie, ça se fête !", Tanitweb, 24/12/2014, <http://blog.tanitweb.com/4-ans-de-youtube-en-tunisie-ca-se-fete/>. Accessed 01/03/2017. Still most Tunisian rappers could not earn money from their youTube videos. This happened in particular because of the poor enforcement of author's rights in the country: as a result, most local rappers could not claim authorship on their own songs. See [reference removed].

${ }^{16}$ For a broader analysis of the economy of the Tunisian rap scene, see [reference removed]

17 On some of these cases, see Julie Green, 'Le Long Combat du Rap Tunisien', SURL Magazine, 28/11/2015. http://www.surlmag.fr/rap-tunisien-emino-2015/ Accessed 3/3/2017.

${ }^{18}$ Boulicia Kleb's video: https://www.youtube.com/watch?v=6owW_Jv5ng4. Accessed 21/10/2016. On the Weld el 15 affair, see 'Weld El 15, Verdict: 6 mois avec sursis', Huffington Post Maghreb, 2/7/2013.http://www.huffpostmaghreb.com/2013/07/02/weld-el-15-libere_n_3532403.html?ref=topbar.Accessed $21 / 10 / 2016$.
} 
the heroes of 2011, and an everyday life of stigma and marginalization. In the next section I will trace the genealogy of this ambiguous condition.

\section{Beyond the Tunisian miracle}

During the regime era, low income quarters and their population were quasi-invisible. The slums' invisibility was constructed by the regime and, in turn, constructed the regime itself, by guaranteeing popular consent. Such a construction served a narrative that celebrated Tunisia as an economic and cultural exception in the MENA region. The Tunisian political establishment, and its allies in Europe and the United States, boasted about the 'European' growth rate of the country, its tolerant Islam and secular society, and the mild character of the regime itself, which appeared on a slow but gradual path towards effective democracy.

Béatrice Hibou ${ }^{19}$ has showed how the narrative of the "Tunisian exception" constituted the main instrument of regime power in the country, way beyond the - however capillary and fierce repressive apparatus constituted by the police and the cells of Ben Ali's party, the RCD (Democratic Constitutional Rally). The foreign sponsors of the regime - in particular the United States of America, the European Union, and organizations such as the IMF and the World Bank - considered Tunisia as the 'model pupil' of neoliberalism. According to its allies, the country had well received the structural adjustment plans imposed on Tunisia by the end of the 1980s and it had been able to turn the neoliberal recipes into an asset for economic growth and democratic progress. Moreover, Ben Ali's repression of radical Islamists (who constituted the main opposition force in Tunisia) reassured Western countries in the post-9/11 age of fear.

According to Hibou, the successful economic performance of Tunisia was actually obtained through the constant and meticulous manipulation of figures and growth indexes. This play on figures was the basis of a tacit 'security pact' between the regime and its dominated. The pact affirmed the presence of the State and the ruling party as a protection against crime, Islamic terrorism, social and economic insecurity: the political system existed by promising growth, stability, and dreams of modern and 'western-like' consumption.

The 'invisibility' of poverty and social difference was a consequence of such promises: the regime shaped an ideological view of Tunisia as an overwhelmingly middle class country. According to this narrative, almost every Tunisian belonged to the middle classes: sociologist Baccar Gherib shows how official data considered the middle classes to account for $80 \%$ of the population in 2010 . The ideology of Tunisia as a middle class country was engineered through an ad hoc use of survey instruments, so that the category of middle class used by the government was extremely vast. This skewed representation of the Tunisian class system was also upheld due to the concomitant absence of any independent academic research or surveys focusing on the class system in Tunisia ${ }^{20}$. However, the regime went beyond shaping a narrative: it constructed this middle class population - a population that considered itself middle class, desired being middle class, and had middle class dreams of consumption - through the levers of debt and inclusion into the public sector and into relations of clientelism. Tunisians owed their perspectives of economic wellbeing and social reproduction to bank

\footnotetext{
${ }^{19}$ Béatrice Hibou, La Force de l'obéissance: Economie politique de la répression en Tunisie (Paris: La Découverte, 2006).

${ }^{20}$ Baccar Gherib, 'Les classes moyennes tunisiennes entre mythe et réalité. Éléments pour une mise en perspective historique', L'Année du Maghreb no. 7 (2011), 419-435.
} 
credit and to instruments of informal welfare put in place by the State - such as the infamous 26.26., a service of national charity extorted from the population ${ }^{21}$.

The other side of the security pact was constituted by the omni-presence of the State and party apparatus. The regime penetrated every level of the country's public life. Tunisians were constantly monitored, and mistrusted each other as potential spies; they needed ties with the establishment in order to accomplish even the most mundane economic goals. Informal connections with State and party representatives were the key to launch a professional activity and to bypass the law - which was necessary due to the strangling, repressive character of bureaucracy. In turn, this situation of dependence put every citizen at risk of being denounced, and thus reinforced fear as a tool for consensus. These two sides of the security pact maintained social peace in the country, at least until cracks in the system were revealed, in the form of 'middle classes' who could not sustain their standards of living anymore, due to the deterioration of the national economy, the narrowing down of social mobility patterns, and heavy indebtment in a time of worldwide economic crisis. The Tunisian revolution can, indeed, be understood as a consequence of the rupture of the security pact ${ }^{22}$.

\section{Lifestyles in the hood}

The representation of Tunisian society as middle class-centred equated to a representation of classlessness. Poverty and its hubs were concealed by the regime, or considered a residual evil that would soon be defeated. In the political rhetoric, and in the media, the disadvantaged hwem were at the same time nests of criminal activity and informal economy, and less developed niches that would soon be integrated in the national progress by the civilizing mission of the regime ${ }^{23}$. But in prerevolutionary Tunisia being from the slums often meant suffering stigma and exclusion. When a youth from poor quarters of Tunis such as Sidi Hassin or cité Ettadhamen went to the city centre for a walk on the central Avenue Bourguiba, it was not rare for him to be stopped by police, have his documents checked, and be sent back to his neighbourhood. According to $\mathrm{Selim}^{24}$, a rapper from the Melassine neighbourhood:

Still to this day, when I hang around downtown, police check my ID card, they see that I'm from here, and they're like "Melassine? What are you doing here? What are you looking for?" Though we're like 15 minutes away from the centre, we are in the centre. It hasn't changed after the revolution [Interview: Selim, 19/3/2015. Translated from French].

Therefore, the narrative of classlessness was matched by practices of exclusion that blended the concealment of poverty with the overt repression and obliteration of the poor. This blend of invisibility and repression caused the Tunisian social structure to be imagined by Tunisians in a curiously paradoxical way: on the one side, everybody was 'middle class'; on the other, a folklore of representations of inequality, expressed by symbolic and allusive languages, permeated the Tunisian ethos.

\footnotetext{
${ }^{21}$ Hibou, La Force de l'obéissance. (see note 15)

${ }^{22}$ Béatrice Hibou, 'Tunisie. Économie politique et morale d'un mouvement social', Politique africaine vol.121 no.1 (2011), 5-22.

${ }^{23}$ Olfa Lamloum and Mohammed Ali Ben Zina (eds.), Les jeunes de Douar Hicher et d'Ettadhamen. Une enquête sociologique (Tunis: Éditions Arabesques, 2015).

${ }^{24}$ All personal names have been changed in order to protect the privacy of informants.
} 
These representations of social difference were articulated through a range of ambiguous determinants: the neighbourhood or the city of origin; language habits (whether emphasizing Tunisian dialect, modern standard Arabic, or French); modes of consumption (for example, the habit of buying groceries at "traditional" open-air markets or at expensive French supermarket chains). In the area of the capital city, the coastal suburb of La Marsa, that hosted many expatriates and intellectuals, was "naturally" considered a sophisticated and progressive place, and so were its inhabitants; on the contrary, neighbourhoods such as the dispossessed Jbel Jelloud were widely reputed poor and dangerous. Practices such as blogging or the passion for electronic music stereotypically identified a youth as a member of the progressive, intellectual, francophone elite. Tunisians from the South were seen as comically backwards, and their accent and supposed gullibility were parodied in TV shows. The new Islamic bourgeoisies had distinctive modes of consumption: they frequented neighbourhoods and specific leisure spaces whose aesthetics and features were unlike the nightlife zones and the bars that the secular bourgeoisie attended.

Such elements of social difference are perhaps common to every society, but in Tunisian society they were peculiarly strong, because of factors such as the heritage of French colonization and the persisting cultural influence of France, the uneven development of the interior regions and the coastal ones, and the diffusion of 'post-Islamic' ${ }^{, 25}$ lifestyles and sensibilities. Furthermore, those distinctions were aggravated by the political obliteration of social inequality. Their character seemed 'fixed', solid, although in practice they referred to vague and elastic markers of distinction. Reality was, indeed, more complicated than the stereotypes suggested. While a certain neighbourhood was socially imagined as exclusively rich or poor, in reality it was always characterized by a certain degree of social stratification. On the cultural level, most Tunisians blended bourgeois and 'popular' forms of consumption, as well as secular and Islamic cultural suggestions, or western and local influences. But still, those distinctions held a structural significance and acted as a key for Tunisians to imagine the variety of lifestyles in their country.

Lifestyles are a classic sociological concept, whose usages go back to pioneers such as Weber ${ }^{26}$ and Simmel ${ }^{27}$ : the first of these theorists saw lifestyles as modes of life and consumption that are statusrelated, and thus varying within the same social class; the second considered lifestyles as articulations of the tension between individuality and universality ${ }^{28}$. A different approach to lifestyles is offered by Pierre Bourdieu ${ }^{29}$ : for him, lifestyles are precise sets of tastes, life conducts, and interests. Class belonging, and thus one's access to economic and cultural capital, is at the basis of the formation of different types of habitus; in turn, each habitus is at the basis of the formation of different lifestyles, all of which mirror certain individual dispositions as a fruit of the habitus, and work themselves as material exhibitions of one's economic and cultural capital. Lifestyles have also been applied more recently as a crucial analytical tool in youth culture studies. The point of reference is here David Chaney, who saw lifestyles as collective identities, and yet tailored to the individual, developed through the creative, ironic, and reflexive use of consumption ${ }^{30}$. We can see how, in most scholarly

\footnotetext{
${ }^{25}$ On post-Islamism, see Asef Bayat, Life as politics: How ordinary people change the Middle East (Stanford: Stanford University Press, 2013).

${ }^{26}$ Max Weber, Economy and society: An outline of interpretive sociology (Oakland: University of California Press, 1978).

${ }^{27}$ Georg Simmel, 'The problem of style', Theory, culture \& society no. 8 (1991), 63-71.

${ }^{28}$ For an overview on lifestyles, see Luigi Berzano and Carlo Genova, Sociologia dei lifestyles (Rome: Carocci, 2011).

${ }^{29}$ Pierre Bourdieu, Distinction: A social critique of the judgement of taste (Cambridge MA: Harvard University Press, 1984).

${ }^{30}$ David Chaney, Lifestyles (London: Routledge, 1996).
} 
usages, lifestyles represent an understanding of social difference that opposes, or nuances, class analyses. While class, in the Marxist sense, is about relations of production, lifestyle is about actual sets of social behaviour (such as taste in consumption or everyday habits) and their role in fashioning identities. Scholars who prize lifestyles over class consider the latter a deterministic marker of social identities, and prefer lifestyles as more indeterminate (and yet more empirically noticeable) signifiers of identity and difference.

The lifestyles framework proves an interesting angle for the analysis of Tunisian society, because it highlights the connection between two social dynamics. On the one side, lifestyles are a perfect representation of the undetermined and consumption-based idioms of difference circulating within Tunisian social narratives. On the other side, they help picturing the identity-making processes and the agency displayed within global youth cultures and music scenes ${ }^{31}$. I argue that the global hip hop/rap culture offered its Tunisian practitioners some cultural instruments which helped them playing with the cultural repertoire of social differences embodied in Tunisian lifestyles. Tunisian scenesters thus had the possibility to reformulate the stereotypes of social inequality in the language of their scene, and thus obtain subcultural capital. This term, coined by Sarah Thornton on the basis of Bourdieu's concept of cultural capital, designates the availability of symbolic goods and credibility within a youth subculture or a music scene: the distribution of these resources within a scene distinguishes the most cool and underground members from simple parvenus ${ }^{32}$.

Tunisian music scenes developed ethnosociologies: scene-specific accounts of how society worked, and where other scenes fit within the social structure. Ethnosociologies were thus instruments, for the members of the rap scene, to collocate themselves in the space of their scene and of society in general. These possibilities rested precisely on the ambiguities of Tunisian social structure and the lifestyles it articulated. Since those lifestyles were formulated in the rather vague terms of residence, language, and cultural taste, they guaranteed wider margins of manoeuvre than the more deterministic discourse of class belonging. I will now offer two empirical examples of this phenomenon.

While Tunisian rappers tended to identify themselves with the youth from disadvantaged quarters, their social backgrounds were actually diverse. Also, many of my informants underlined the fact that Tunisian rappers often had a school degree, which, in their opinion, clearly distinguished local rappers from the standard MCs struggling in the American ghettoes ${ }^{33}$. To be sure, during my research I have met more lowclass youth in the rap scene than in the metal or the electro scenes, but still the selfascription of rappers among the poor and unemployed was in many cases a conscious cultural strategy. The self-identification of rappers as wled el houma (sons of the houma) worked as a means - although not necessarily a conscious one - to express street credibility and social critique.

The other example concerns the relationship between the rap scene and the 'alternative'/intellectual milieu of Tunis - that is, the cultural scene that connected artists, cyberactivists, left-wing intellectuals and the like. Although it was impossible to trace its contours, this milieu was visible and commonly recognized by the frequenters of the underground political and cultural worlds of the capital city. Many of its members came from the upper classes, had relevant qualifications, and expressed a

\footnotetext{
${ }^{31}$ Stahl, 'It's like Canada Reduced' (see note 5).

${ }^{32}$ Sarah Thornton, Club cultures: Music, media, and subcultural capital (Hanover: Wesleyan University Press, 1996).

${ }^{33}$ See Tricia Rose, Black noise: Rap music and black culture in contemporary America (London: Weseleyan, 1994); Murray Forman, The 'hood comes first: Race, space, and place in rap and hip-hop (Middletown: Wesleyan University Press, 2002; Robin D.G. Kelley, 'Looking for the "Real” Nigga: Social Scientists Construct the Ghetto', in That's the Joint! The Hip-Hop studies Reader ed. Murray Forman and Mark Anthony Neal (New York: Routledge, 2004), 177-200.
} 
culturally cosmopolitan identity. And yet, some youth from less privileged backgrounds frequented this milieu. Those youth often had access to the milieu through their display of an artist lifestyle and the use of subcultural capital. For instance, the cultural and political reputation of rappers made them cool acquaintances in the eyes of some of the capital city hipsters - although their actual lifestyle was more akin to the 'sons of the houma' than to the intellectual bourgeoisie. Some Tunisian youth represented themselves as 'freelance artists' and thus expressed their contiguity with that cultural scene, while they were actually unemployed and made a living out of friends' loans and marginal activities in the milieu itself, such as dealing drugs or working as security staff at cultural events (both functions often fulfilled by rappers).

These examples show how the play onone's youth cultural lifestyle allowed her to play onthe social structure at large - or, at least, on its defining narratives. While post-revolutionary Tunisia inherited its discourse on social differences from the regime era, these practices that reshaped social imaginaries helped the gradual redefinition of that discourse; although, as we will see, this effort of redefinition had its limits. In the next section I will describe the ways in which the rap scene used the houma and disadvantaged youth as tools for such lifestyle manipulation.

\section{Sons of the houma}

Tunisian rap did not invent the neighbourhood as a poetic topos. On the contrary, the hood is perhaps the most typical rap theme all over the world. The globalization of rap imposed to its practitioners an authenticity dilemma: should one keep it real by making music that portrays the truth of her daily life and thus "represents" her local setting, or should one stay authentic to the origins of hip hop culture, reinforcing her ties to the roots of American and global hip hop? ${ }^{34}$. Rapping about the houma provided a solution to this dilemma. The houma was the locus that articulated those two sources of authenticity: it connected the brutal truth of the everyday street experience with the discipline and knowledge that is, the subcultural capital - of rap as a global narrative of the ghetto. The Tunisian neighbourhood was, at once, the unique setting of a rapper's local life and a synecdoche for all the ghettoes in the world. This ambivalence had an extreme example in the music of rappers such as T-MC, from the dispossessed Cité Bechir, in the city of Mhamdia. T-MC rapped in English; his accent and slang mimicked American rap and his lyrics were not about strictly local topics, but could rather refer to the poor and the hoods of any country. And yet his videoclips, for example the one for the song Lifeless $(2016)^{35}$, linked such a universal poetics to a context that was extremely close to the life experience of T-MC: the dismal streets of Mhamdia. When I interviewed T-MC, he explained to me how this very link between personal life and global art drove him towards rap:

I figured out that the only way to take my life in my hands was the way of rap music, that this was the only thing I could describe myself into, through which I could describe the problems of my people. This is the only music, the only art, that can send my message to the world. I survive every day like this, fighting against the government and talking to my people, not only in English, but also in a very good literary Arabic [in the political video speeches that T-MC often published on his Facebook page]. But I

\footnotetext{
${ }^{34}$ See Andy Bennett, 'Hip-hop am Main, rappin'on the Tyne: Hip-hop culture as a local construct in two European cities', in That's the joint! The Hip-Hop Studies Reader (see note 33)

${ }^{35}$ Lifeless's video: https://www.youtube.com/watch?v=st4uELNXG5k Accessed 9/11/2016.
} 
never sing in Arabic. I chose to talk to the world with my songs, and if I talk to the world I have to do it in English [Interview: T-MC, 1/6/2015].

Other Tunisian artists used a different practice of localization of their music: what Murray Forman defines the extreme local ${ }^{36}$. The extreme local is the use of "micro" markers of residence and provenance such as postcodes, address numbers, names of neighbourhoods, codes of transport lines and the like. Through the extreme local, rappers 'represent' their place, and at the same time claim an identity that is strengthened by representation itself. Usage of the extreme local was visible all across the Tunisian rap scene: the crew from the Kabbariya quarter was called K.A.B.B.A.; artists like Klay and Phenix used the abbreviation BBJ in their stage names in order to signify their hood, Bab Jdid; the crew 24 All Stars referred to the bus line that travelled from Tunis to their headquarters in the city of Mourouj; the crew South School from the southern Gafsa region used many references that collocated it into the country's inland.

In some cases, the extreme local acts in the opposite way: rap projects its symbolization on the local environment - as when a crew marks its neighbourhood with graffiti. In the above-mentioned Bab Jdid houma, the reputation of rapper Klay BBJ (one of the most admired in Tunisia) strongly influenced neighbourhood life. Klay showed the streets of Bab Jdid in his very popular videos, and he talked about his people in the songs. Over time, Klay BBJ became a symbol of Bab Jdid itself, reconfirming the reputation of rich folkloric and cultural production of the neighbourhood.

The poetics of the houma rested on an ambivalence between the expression of hardship and the celebration of pride. This formula, itself not uncommon in global rap culture, mirrored the equally ambivalent narrative about disadvantaged youth in post-revolutionary Tunisia, both dismissive and celebratory. MCs sang the hood reality as one of deprivation, police harassment, daily violence. Its public space was marked by emptiness, cafes and mosques often being the only social spaces available. Rappers claimed to represent the protagonists of this space: the young men who 'held the walls' in a present of permanent waithood ${ }^{37}$. This social category had a recognizability beyond rap narratives: public and academic discourses characterized the sons of disadvantaged hwem as unemployed or casually employed men, aged from fourteen to thirty years old, unmarried, often living with their parents, incapable of succeeding in transitioning to adulthood because they could not afford the basic status symbols that marked this transition - basically, a house, a stable job, a wife ${ }^{38}$. They spent the day experiencing boredom, telling jokes or having fights with friends, and engaging in petty hustling. Women, in contrast, were less visible in the same spaces, and more confined in the space of home, school, or street markets.

Some musicians framed this condition of emptiness and deprivation as a political design, with police as the material executor of such a design. Rappers commonly hated police. They did not consider policemen as a simple State emanation, but rather as corrupted persecutors of the neighbourhoods, who stormed the hwem in search of bribes and the pleasure of exerting power (one of my informants even called them 'a concurrent gang'). The idea of the neighbourhood situation as a political

\footnotetext{
${ }^{36}$ Forman, The 'hood comes first(see note 33).

${ }^{37}$ See Alcinda Honwana, The Time of Youth. Work, Social Change, and Politics in Africa (Boulder: Kumarian Press, 2012); Stefano Pontiggia, "'Every day is copy-and-paste": waithood among Tunisian men', Allegra Laboratory 20/4/2016 http://allegralaboratory.net/every-day-is-a-copy-and-paste-waithood-among-tunisian-men/ Accessed 9/11/2016.

${ }^{38}$ See Amin Allal, 'Avant on tenait le mur, maintenant on tient le quartier! Germes d'un passage au politique de jeunes hommes de quartiers populaires lors du moment révolutionnaire à Tunis' Politique africaine vol. 121 n.1 (2011), 53-67.
} 
construction, and of police as the moral agents of it, is visible in the words of rapper Taher, from the Sidi Bechir hood in Tunis:

It is the system that built this neighbourhood. It built the hood, and then it besieged it. There's the Sidi Bechir police station, there's another one up there... It's surrounded by police, I tell you. Police comes from... form Gorjani station for example, they come, I'd say, once or twice a day. They earn their money and then they go back, you see? They take their "commission". It's basically a racket. And in all neighbourhoods it works like this [Interview: Taher, 8/8/2014. Translated from French].

At the same time, the hood was a source of pride. It was a social ambit marked by neighbourhood solidarity and warm interpersonal relations in the elsewhere cold social climate of the city ${ }^{39}$ ). Pride also came from hard living itself: some of my informants described this in terms of honour, the honour of coming from a place into which some of their compatriots would not dare to step. For others, the houma was just everything; they could not imagine their life anywhere else. As Kais, a rapper from Bab Jdid, put it: "I'm one of the people who came to know the world here. I opened my eyes here, most of my friends are here, my life is here, and I spend most of my time in here" [Interview: Kais, 3/6/2015. Translated from Arabic].

The hood was thus lived as an integral reality whose pleasures and evils were inextricable. An example is the song L'Manfi (The Exile, 2014) ${ }^{40}$ by the group Empire, who represented the Bab el Fellah and Sidi Mansour neighbourhoods:

We keep on advancing in places where guys of my age perish

Those who come buy [drugs] in Sidi Mansour get robbed

This quarter where all the money is hidden by the walls of Lucifer

You get killed if you trespass your boundaries, everything is a game

Like thugs

We fuck our brains without any money and the dessert is chocolate [hashish]

[...]

I grew up moving, I concealed my cards

Bab el Fellah is not a movie, wake up, you dormant

Here, when a child wants candy, the adults make you drink boukha [a Tunisian liquor]

It's the language of the suqs [the open air markets], the harassment of the suqs

[...]

For the people of my quarter, Chiheb and Haha

We live in a country where the system fishes us

Bab el Fellah. We'll only rest in our graves.

The video for L'Manfi ends with a credits section citing several youth from the houma that Empire represented. A similar strategy appears in other videos, such as the one for Hchinahoulna (We fucked ourselves) by Klay BBJ and Phenix: the credit section attributes the direction of the clip to the wled el houma, and continues listing some of them who have contributed to the making of the video. The L'Manfi video is dedicated to Walid Denguir, a young man from Bab Jdid who died while he was

\footnotetext{
${ }^{39}$ Ridha Ben Amor, Les formes elementaires du lien social en Tunisie (Paris : L'Harmattan, 2011); Lamloum and Ben Zina, Les jeunes de Douar Hicher et Ettadhamen (see note 23).

${ }^{40}$ L'Manfi's video: https://www.youtube.com/watch?v=jgVpUHjlXdQ Accessed 9/11/2016.
} 
under police custody: while Denguir's corpse showed traces of torture, authorities denied any police violence on the young man, and the coroner suggested 'cannabis overdose' as the cause for his death ${ }^{41}$. Walid Denguir is also the protagonist of another Empire video, Hommage - Walid Denguir (2013) ${ }^{42}$ (a montage of scenes of police violence and the making of a graffiti portrait of Denguir in Bab Jdid), and of a song by Klay BBJ and Sniper MC called Hommage Denguir (2014) ${ }^{43}$. These songs and videos make the identification between the houma as a community place and the troubles of disadvantaged youth clear. Furthermore, they characterize the dispossessed hood as a victim of the institutions, and police as the nemesis of the local youth - Denguir, a criminal in the eyes of the authorities and in the media official discourse, is tributed and dignified, while police is bashed as an enemy.

Pest, a young MC from Fouchana city, presented in his songs the same ambiguity between the houma as a warm place and the houma as a locus of struggle and misery. In Nafs al Mouaten (The Same Citizen, 2014 $)^{44}$ he describes the unchanging routine of a 'son of the houma'; in Feeling so hood ${ }^{45}$ he sings the pain and the honour of living in a disadvantaged quarter:

Evenings are full of sorrow,

we never change the needle and bodies are filled with tattoos

Tattoos and anxiety, it's become a burden

He became an alcoholic - that's normal, we're always alright

God, we left the bourgeois pile up [the money]

[while] We are the ones who believe in honour and in the hoods,

Prisoners are the poor, police is the responsible,

Here, we burn the shit [hashish]

One year of prison and a cowl-less Vespa,

Drift away from checkpoints,

Pantakol [glue] and Magic [methanol] fill the plastic bags,

The group gathers on the street,

Hunger pushes you to tear out by force,

You are invited to Mornaguia [prison],

Hard to find anybody [judicially] clean,

Hard to find anybody weak,

We are afraid of the one above [Allah] and not of you

[...]

The State seeks order, we seek vengeance.

When I interviewed Pest, he was adamant in his refusal to live anywhere else than in the houma. He loved living in Fouchana, although life there was often hard, full of fights and police violence:

\footnotetext{
${ }^{41}$ Céline Lussato - 'TUNISIE. Walid Denguir, mort en détention, a-t-il été torturé?', L'Obs, 8/11/2013. http://tempsreel.nouvelobs.com/monde/20131108.OBS4713/tunisie-walid-denguir-mort-en-detention-a-t-il-etetorture.html Accessed 25/10/2016.

${ }^{42}$ Hommage - Walid Denguir's video: https://www.youtube.com/watch?v=Ao3NQyQ8anU Accessed 9/11/2016.

${ }^{43}$ Hommage Denguir's: https://www.youtube.com/watch?v=gSqX8oXrMkE Accessed 9/11/2016.

${ }^{44}$ Nafs el Mouaten's video: https://www.youtube.com/watch?v=kPZct6x22WA

${ }^{45}$ Feeling so Hood's video: https://www.youtube.com/watch?v=OLId7dOcTwU Accessed 9/11/2016.
} 
I could never live in El Menzah [a well-to-do suburb of Tunis], I hate chic quarters. I have a problem with the bourgeois, because they detest us, the poor. I hate the bourgeois, they're the main subject in my songs. I like living in my neighbourhood with the poor, that's a good life. I love my life here, I love my neighbourhood, I won't disown it. It's true, we have problems, but that's still the best possible life. I wouldn't like to be one of the rich. I'd only like to travel away in order to make music properly [Interview: Pest, 22/6/2015. Translated from Arabic].

.Another reason why the hood became the source of pride was linked to the revolution. Disadvantaged neighbourhoods were the hotbeds for the insurrection. This began in the inland regions, where social unrest was propagated from Sidi Bouzid. As the movement reached the bigger cities, including Tunis, the poorer neighbourhoods on the outskirts were the first places to revolt. Male youth in those quarters did not live the revolutionary moment simply as the overthrowing of a dictator; they saw it as a way of becoming mature and taking life in their own hands after a never-changing routine of social spite and lack of perspectives of realization. Through the organization of 'neighbourhood committees', boys started patrolling their quarters; they kept police and RCD militias away from their streets. As Amin Allal put it, politicization meant to them a way of becoming men: they used to be regarded as delinquents, and then they came to be celebrated as heroes ${ }^{46}$.

Revolution can, indeed, be seen as an irruption of the houma youth into the national self-image of Tunisia. The long-neglected poor came to be, for an instant, the true political subject in the country's historical shift. In the aftermath of revolution, rap became the official language that celebrated the mythology of this event. Rap did not only celebrate the forgotten houma and denounce its problems; it also claimed the sons of the houma as protagonists, subjects, and narrators of the new Tunisia. Conversely, rappers felt invested by the houma youth as their official spokespersons, and as quasipolitical representatives. This reciprocity is visible in songs by rappers like Klay BBJ, Phenix, or Absy. An example is the song Hchinahoulna (2013) by Phenix and Klay BBJ ${ }^{47}$. Klay sings the line 'At the next elections, I will vote for the drug dealer from the houma', while Phenix ends the song with the following words:

\section{Bab Jdid is in the place}

Politics in a suit, basically under it it's all whores and transvestites

When I insult you my people rejoice, insulting you is my bread

Old men, our rap is more listened to than your president.

In their song, Klay and Phenix stated a cleavage that was, at the same time, cultural, generational, and political. On the one side there were the youth from the houma, their urban lifestyles, and rap as their poetic expression and device of representation. On the other, 'the system', composed of old people whose power thirst was seen as the reason for the injustice governing the country. Both rappers sang from a markedly revolutionary point of view, one that urged the people to complete the 2011 uprising by fighting the 'democratic' political establishment. And yet, in a sense, they pointed exactly at the paradox of post-revolutionary Tunisia. The surge of houma soundtracks, with tragic irony, ended up coinciding with a rapid new form of political and social marginalisation for disadvantaged youth.

\footnotetext{
${ }^{46}$ Allal, 'Avant on tenait le mur, maintenant on tient le quartier!' (see note 30 ).

${ }^{47}$ The song video: https://www.youtube.com/watch?v=7P4PaNu6t00 Accessed 9/11/2016.
} 


\section{Conclusion}

The hoods were celebrated for some months before earning a new stigma: the one of being cradles for terrorism ${ }^{48}$. Unemployment worsened, while the rate of youth participation in elections dropped. Youth were once again publicly represented as a problem, making it into the news only in relation to the denouncing of youth delinquency, arrests for cannabis smoking, jihadism, or violent unrest ${ }^{49}$. At the same time, discotheques in the exclusive Gammarth area hosted bourgeois youth singing along to Houmani. Kafon became a pop star, and he even participated in the 2014 presidential election by backing two candidates ${ }^{50}$. The rap scene produced an array of narratives that succeeded in reworking the social imaginary of post-revolutionary Tunisia, but the transformations of this imaginary could well overlap with the persistence of social marginalization.

In addition to that, the whole exercise of 'singing the houma' existed upon an ambiguity: the tension between the vivid realism of the extreme local and the mythological idealtype of the hood and its youth. The houma was sung as a hypostasized, homogeneous reality: it was not rare for rappers to tell me: 'I have no songs about my specific houma, but I sing about the houma in general'. This construction encompassed realities that had different histories, different social conditions, and were even different administrative entities (from bigger cités to tiny blocks). Furthermore, the houma was not a smooth space, but rather a socially complex and diverse environment - exactly as rappers represented disadvantaged youth, but were not necessarily disadvantaged themselves.

Tunisians constructed the houma's complexity by emphasizing one of the different elements that they usually ascribed to their neighbourhood: local identity, 'traditional' ways of life, urban hardship. The simultaneous or alternative evocation of these aspects helped producing the houma as a malleable idealtype, one that gave to its inhabitants a strong political identity. The link between the hood and Tunisian youth produced a distinctive form of sociability, separate from the urban elites and from the political establishment. As such, it claimed dignity as an attribute of the 'grassroots' Tunisia of the neighbourhoods. This claim of dignity was in line with the revolutionary battle: the honour and feelings of revenge sung by rappers in hood-centred songs belonged to the genealogy of the revolution. As for them, rappers turned their activity of representation of houma youth as a source of subcultural capital.

The art of rapping about the neighbourhood displayed agency over the narrative of social difference in Tunisia. By producing a specifically hip hop ethnosociology, tt could manipulate the indeterminacy of the lifestyles expressed by the local ethos, and help reconfiguring the social narrative beyond the spite that had marked social relations under the Ben Ali regime. As a participant in the presidential elections of 2014 defined himself a houmani candidate ${ }^{51}$, as the narrative of the houma became glamorous, as disadvantaged youth became for a while the protagonists of the new Tunisia, such a reconfiguration seemed at hand. But the return to marginality of Tunisian youth in the postrevolutionary political landscape showed how the transformation of a narrative has only indirect

\footnotetext{
${ }^{48}$ Lamloum and Ben Zina, Les jeunes de Douar Hicher et Ettadhamen (see note 23) describe this situation with regard to the Douar Hicher and Ettadhamen neighbourhoods.

${ }^{49}$ For an excursus on such a wave of criminalization of youth, see Debora del Pistoia and Lamia Ledrisi, 'Tunisia's fight against its revolutionary youth', Open Democracy, 07/01/2016, https://www.opendemocracy.net/arabawakening/debora-del-pistoia-lamia-ledrisi/tunisia-s-fight-against-its-revolutionary-youth Accessed10/03/2017. .

${ }^{50}$ Chennaoui, 'Elections 2014' (see note 10).

51 "Mehrez Boussaïane : Je suis un candidat "Houmani"', Mosaique FM, 6/11/2014.

http://www.mosaiquefm.net/fr/index/a/ActuDetail/Element/43881-mehrez-boussaiane-je-suis-un-candidat-houmani Accessed 8/11/2016.
} 
consequences on the transformation of reality. The ambiguity that allowed Tunisian rappers to play with the Tunisian social imaginary was also the main limit of their symbolic work. The quest for dignity and social recognition was far from over. 